\title{
FÓRUM TEATRO, CINEMA E ORGANIZAÇÕES
}

\author{
Peter Pelzer Consultor Independente, Alemanha \\ E-mail: ppelzer@t-online.de
}

Ana Paula Paes de Paula Doutoranda em Ciências Sociais, UNICAMP

E-mail: appaula@uol.com.br

Nas últimas décadas, abordagens não convencionais começaram a interessar os estudiosos de organizações e management. Cada vez mais, visões alternativas são consideradas úteis para compreender fenômenos sociais e comportamentais, bem como para inspirar o desenvolvimento de novas teorias e práticas administrativas.

Neste contexto, abordagens baseadas em visões teatrais e cinematográficas vêm ganhando espaço. A metáfora teatral inaugurou uma nova era de interpretação nos estudos organizacionais, que também despertaria o interesse pela metáfora cinematográfica. O trabalho seminal de Mangham e Overrington, Organizations as theatre (1987), preparou o terreno para a difusão destas abordagens. Desde então, conferências foram organizadas e muitos artigos foram publicados.

O uso do cinema e dos filmes para estudar organizações é uma decorrência, ainda que parcial, da metáfora teatral. O cinema e a televisão transformaram nossas sociedades em culturas visuais. As representações do real estão substituindo a experiência vivida de tal maneira que não é difícil começarmos a questionar em que mundo nós estamos realmente vivendo.

Seguindo este insight, nós podemos pensar o filme como uma representação que espelha a realidade organizacional. Assim, a metáfora cinematográfica nos ajuda a refletir sobre as questões da produção da realidade nas organizações, pois decodifica representações, construções e desconstruções.

Todos sabemos que os filmes herdaram das peças de teatro dimensões dramáticas, cômicas e trágicas. No entanto, no teatro há sempre uma consciência do público sobre as diferenças entre palco e platéia, peça e realidade. Já no cinema, estas diferenças apresentam tendência à dissimulação, pois a tela parece apresentar nossa realidade cotidiana.

Assim, o filme não significa somente um meio de investigar as representações que acontecem nas organizações, mas também um instrumento valioso para explorar a construção de realidades e o fenômeno do poder.

O propósito deste fórum é convidar o leitor a explorar artigos inspirados nestas novas abordagens. Os dois primeiros são baseados em teatro e os últimos, em cinema. No artigo de David M. Boje, Resistência carnavalesca ao espetáculo global, o autor usa a teoria crítica pós-moderna para explorar as relações entre espetáculo, carnaval e administração pública. A inusitada combinação resulta em um questionamento da captura da esfera pública por duas formas de resistência: os conflitos teatrais encenados pelo espetáculo da mídia e a resistência "carnavalesca" ao discurso da globalização.

Já no artigo Teatro e Mudança Organizacional, Georg Schreyögg argumenta que o teatro organizacional pode ser uma ferramenta poderosa nos processos de mudança organizacional, na medida em que confronta situações da vida cotidiana, além de padrões de comportamento e de conflitos que habitam o subconsciente dos envolvidos.

No artigo Dead Man: um encontro com o passado desconhecido, o co-autor desta abertura, Peter Pelzer, utiliza o filme de Jim Jarmush para discutir os processos de fusões e aquisições no mundo organizacional, analisando os casos de fracasso que ocorreram no setor bancário alemão. Dilemas da vida pós-moderna, como a tendência ao esquecimento do passado e à exaltação do futuro, permeiam o artigo e convidam o leitor a reflexões existenciais.

$\mathrm{O}$ artigo de Heather Höpfl, Vertigo e o sublime trágico encerra o fórum. Enveredando pela tragédia dirigida por Alfred Hitchcock, Höpfl procura demonstrar que as idealizações humanas e a visão masculina do mundo moldam as organizações contemporâneas. Questões de gênero e revelações sobre a psique humana permeiam as interpretações da autora, fazendo da leitura uma experiência quase tão vertiginosa quanto assistir ao filme.

Além de debater questões de interesse para o mundo corporativo, bem como os problemas gerados pelo comportamento humano nas organizações, este conjunto de artigos tem a qualidade de provocar nossas emoções. Assim, a leitura de alguns deles pode gerar interpretações inesperadas e provavelmente ganhará novas dimensões se estas impressões forem compartilhadas com outros leitores.

Esperamos que todos tenham leituras estimulantes! 